\title{
The Disasters of War
}

\author{
Avery F. Gordon
}

\section{| Against the Common Good [1]}

The United States is at war again, as it has been for much of its history. Today, it is waging a war on terror and expanding its military installations on an unprecedented global scale, waging a war on crime and creating the largest carceral complex in the world, and waging a war on Iraq. Although the latter is now officially over and won (the U.S. occupation of Iraq being, from the state's point of view, an exercise in democratization, so-called). [2] In the course of the prosecution of the war on terror and the war on Iraq, photographs have attracted unusual public attention and controversy. Newspapers openly report that military regulations forbid taking or distributing images of returning dead U.S. soldiers, a preemptive patriotic control measure that, in the main, has backfired badly. [3] Independent news agencies question the reliability of embedded print and television photo/video, confirming the staging of fake war victories, such as the "spontaneous" toppling of the statue of Sadaam Hussein in central Baghdad, and the erasure of actual war carnage, such as in the destruction of Fallujah. And, most noteworthy, the public distribution of the amateur photographs of torture and abuse at Abu Ghraib prison now defines the moral corruption of the war and the subsequent occupation. [4] The latter have received considerable attention, exemplified in Susan Sontag's (2004) last published essay which angrily denounced the photographs, their having been taken at all, and the Bush administration that authorized them and then treated their exposure as nothing more than a public relations disaster.

The question of war and photography thus looms large today. Without pretending to do justice to the subject, but to provide a brief remark, I turn not to Sontag's essay on Abu Ghraib, but to her last book, Regarding the Pain of Others (2003). Sontag returns to the subject of photography, earlier considered in the celebrated On Photography (1977), and in this book focuses on the role that photographs play in war. Decisively influenced by her wartime visits to Sarajevo, Regarding the Pain of Others is more directly concerned with the political function of war photographs or what she calls "shock" or "atrocity" photographs. Do images of war's atrocity inhibit or encourage war or numb reaction altogether, she asks? What are the social and political results of viewing pictures of the disasters of war?

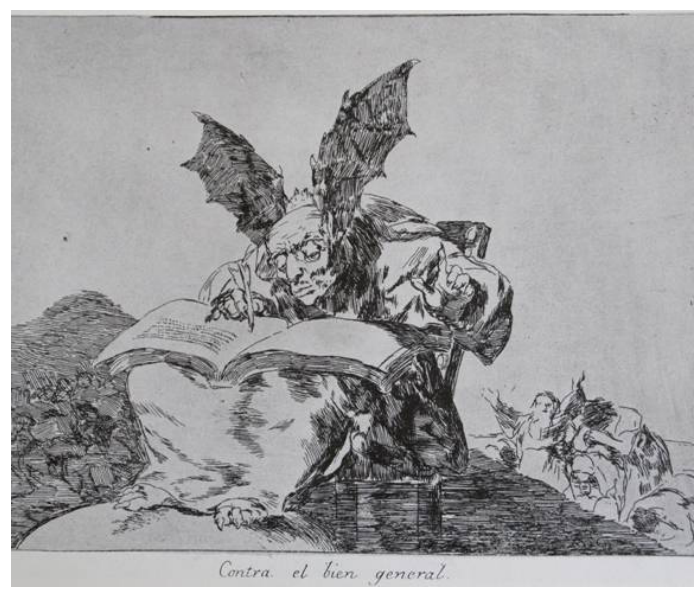




\section{Bury Them and Keep Quiet}

Her answer, in short: "Harrowing photographs do not inevitably lose their power to shock. But they are not much help if the task is to understand. Narratives can make us understand. Photographs do something else: they haunt us" (Sontag 2003:89). Sontag promotes understanding or what she later names "thinking" and "being serious" and, when you're reading, the precise authoritative tone of "There's nothing wrong with standing back and thinking" is unmistakably familiar (2003:118). Thinking is preferred to remembering, an "ethical act" of which there is nevertheless too much; too much injustice to remember and too much remembering of all of it (Sontag 2003:115). Thinking is also contrasted to photography itself, the medium through which we now "more and more" remember and whose modus operandi is haunting. While "there now exists a vast repository of... atrocious images [that] haunt us" and that "perform" the "vital function" of telling us "what human beings are capable of doing," (ibid) these photographs and their haunting effect seem to block, rather than enable understanding or serious thought. Sontag's emphasis on "standing back and thinking" is an important means by which she calls the viewer to accountability and to politics, however, there's something profoundly amiss in her presumptive segregation of haunting and understanding.

I'll return to what's amiss, but note that there is a larger question Sontag avoids altogether: what does or should a picture of war or poverty or exploitation or displacement or dispossession or illegality look like? She takes for granted - it is a common assumption - that the paradigmatic horror of war looks like a dead or broken body. Death and mutilation are part of war's barbarity and also powerful icons of it. But what if we consider the causes of war and militarism more generally? What is the picture of a society that spends, like the United States does, close to $\$ 800$ billion dollars a year on military, police, prisons, and so-called national security? How do we envision the social systems that produce pain, injury, exhaustion, aggravation, loss of life, social and civil death? While we can see these effects on a person's body, how do we show their effects on the mind, the spirit, or the culture? How would we make a picture of what we have lost that we don't even know we've lost? What is the picture of a society that doesn't know it has lost its own capacity for self-definition and self-creation?

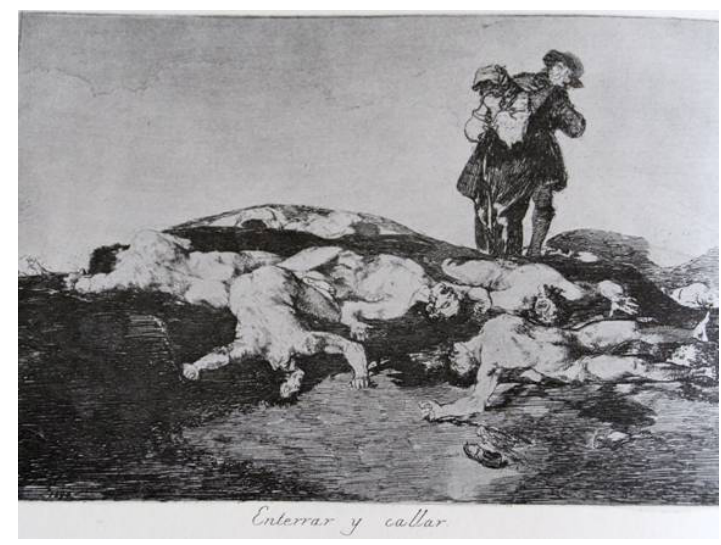

\section{Rabble}

Haunting makes a more telling appearance elsewhere in Regarding the Pain of Others. In the course of surveying the formidable archive of anti-war art and photography (she has just been describing Ernst Friedrich's radical antimilitarist album Krieg dem Kriege! (War Against War! 1924)) that by now, she insists, withdraws any rights to "innocence" or "ignorance," Sontag portrays a scene in Abel Gance's extraordinary anti-war film J'Accuse (1938).

'Morts de Verdun, levez-vous!' (Rise, Dead of Verdun! ), cries the deranged veteran who is the protagonist of the film, and he repeats his summons in German and in English: 'Your sacrifices were in vain!' And the vast mortuary plain disgorges its multitudes, an army of shambling ghosts in rotted uniforms with mutilated faces, who rise from their graves and set out in all directions, causing mass panic among the populace already mobilized for a new pan-European war. 'Fill your eyes with 
this horror!' It is the only thing that can stop you!' the madman cries to the fleeing multitudes of the living, who reward him with a martyr's death, after which he joins his dead comrades: a sea of impassive ghosts overrunning the cowering future combatants and victims of la guerre de demain. War beaten back by apocalypse (2003:16-17).

Sontag focuses on the film's most celebrated scene and an unforgettable image: dead soldiers rising from the then new mass cemeteries covered with white crosses. [5] But almost everything about Sontag's rendering of scene and film misses Gance's message and the film's lessons about haunting. A remake of his 1918 version, J'accuse opens with some of the earlier film's documentary footage of relentless urban bombing-reminiscent of Baghdad todayand the notorious WWI trenches. The noise is a deafening accompaniment to the carnage as we are introduced to the protagonist, Jean Diaz. Hardly a "deranged" veteran, he is the sole survivor of his World War I patrol, a gentle group of often handholding politicized and self-aware working class men who foresee their own deaths at Verdun. Believed dead, Diaz is only discovered barely alive during the tearful roll call of the dead when he is literally raised from the ground. Returning home after the armistice, Diaz becomes committed to preventing any future wars, and as "veteran," "researcher", "poet," and "utopian" (his self-designations), he creates an invention designed to prevent war. This invention is stolen by a deceiving industrialist/politician, a representative member of the distant ruling elite who, the film reminds us, sent 12 million men to unjustifiable slaughter and who uses it to foment war not peace. The corruption of his aims and his sense of complicity coincide with Diaz's growing perception that another war is imminent. It is only at this point and after his J'accuse speech falls on the deaf ears of the middle managers and white collars like himself to whom it is directed that Diaz is deemed mad. But, as he himself says, "I can't explain it. I'm not crazy. My house is full of fear." But there is something amiss with him. He is haunted by war past, present and future. He is haunted by how quickly the dead have been forgotten, by the lies of propaganda ("les belles phrases"), and by how quickly new "divisions among men" have been organized. It is only after his raised voice fails to raise the consciousness of the living to the concrete pains and losses of war's imperialist and industrialist abstractions that he tries to raise the dead; it is only after he tries to raise the dead that he is considered deranged.

And raise the dead he does. Sontag is correct to say that Diaz summons the war dead in French, German, and English, but what's notable is the internationalism - the war dead from "all countries" are called and arise in solidarity. And when they arise, despite some initial panic, we see not the force or the face of horror, but spectral men, some sad, some with mutilated faces and limbs, moving together, holding each other up when unable to walk unassisted. This is far from an apocalypse. The ghosts of Verdun do not terrorize the living. Rather, as the village residents note, they are making their way home across a Europe, not haunted by the dead, but by the specter of war itself.

This haunting is also clearly an active social movement, not a "cowering future." In these scenes, everybody (and magically everything else-trees, roads, houses) is on the move! Jean Diaz neither dies nor becomes martyr; the last we see him he's still conjuring the dead, helping to create an uprising of people who form a multitude that refuses war. In fact, this grand scene is not, pace Sontag, how the film concludes. Jean Diaz raises a pacifist army of soldier ghosts and they win their cause. J'accuse ends under the banner of "universal peace" at a "convocation" of nations that looks much like a rousing meeting of the U.N. General Assembly were its members World Social Forum participants rather than heads of state. At this assembly, full of African and Asian faces, immediate "disarmament" is established and war is "abolished." To great cheers, war is proclaimed "dead” ("La guerre est morte!”) and the "world renewed." The final shot shows a mingling of ordinary people, the living and the ghostly almost indistinguishable, on their way to a more just and equitable home.

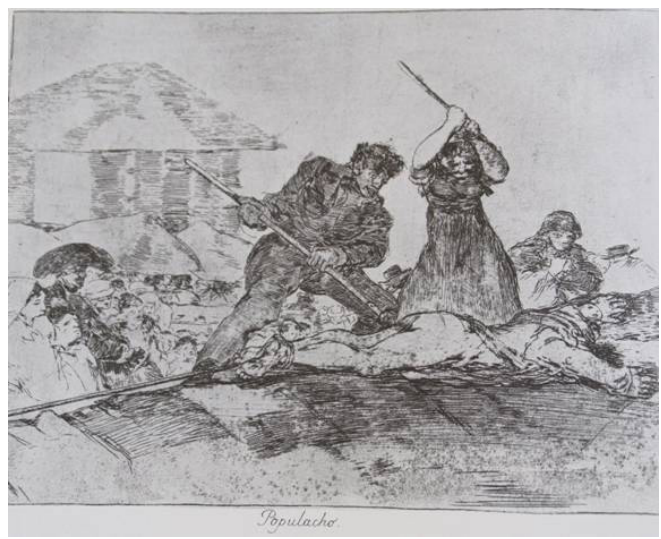




\section{What More Can One Do?}

The refusal of war, the non-necessity of war, is the lesson Gance's ghosts help the living to realize, but it is not the lesson that Sontag extracts, either from J'accuse or from Virginia Woolf, whose reflections on the origins and nature of war, Three Guineas, also appeared in 1938. Regarding the Pain of Others begins with Woolf's proposal to the man who has written to her to ask "how in your opinion are we to prevent war?" that they should look together at some pictures. The pictures are disturbing photographs of mutilated or dead women and children and bombedout houses sent by the Spanish government "about twice a week" in the winter of 1936-37. Woolf asks "whether when we look at the same photographs we feel the same things" (1938:10). Her reply: "When we look at those photographs...however different the education, the traditions behind us, our sensations are the same...You, Sir, call them 'horror and disgust'. We also call them horror and disgust... War, you say, is an abomination; a barbarity; war must be stopped at whatever cost. And we echo your words. War is an abomination; a barbarity; war must be stopped" (1938:11).

Sontag is fixated on exposing Woolf's mistake in treating the photographs as ethically transparent, obvious justification for the elimination of war. As Woolf herself writes, "Those photographs are not an argument; they are simply a crude statement of fact" ((1938:11). Sontag's reasoning consists of two now-commonplace observations of our own era. First, photographs do not show war as it is, but war as it is seen by the photographer and the viewer of the photographs. As Sontag concisely puts it, "Photographs of the victims of war are themselves a species of rhetoric" (2003:6), institutionally produced, one should add. Her second and accentuated argument is equally emblematic: there is no "we" of good-willed and like-minded people that can be presumed to react in the same way. As she writes: "It is this 'we' that Woolf challenges at the start of her book: she refuses to allow her interlocutor to take a 'we' for granted. But into this 'we,' after the pages devoted to the feminist point, she then subsides. No 'we' should be taken for granted when the subject is looking at other people's pain" (2003:7). [6] Both of these points are, analytically speaking, true enough, even if their specific impacts depend on whether you treat them as crippling prohibitions or friendly facts. [7] There is, however, a "we" that Sontag takes for granted and it is the one that helps us grasp why she rejects Abel Gance's veteran ghosts and Woolf’s haunting photographs.

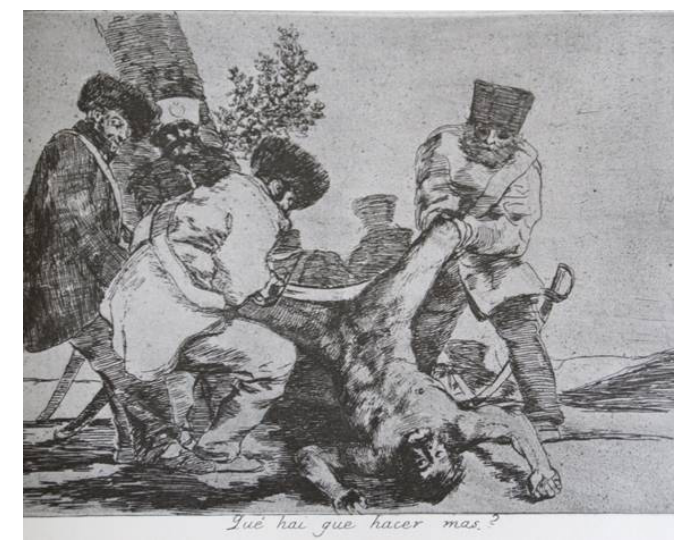

\section{Vain Laments}

Sontag's understanding of war and her larger regard for the pain of others rests on a denial of the potential power of haunting to stop war. The denial is not premised on her brief for measured rational thought as a more effective method of social understanding and grounds for political contest than traumatic horror occasioned by visceral imagery. Neither her pointed criticisms of naïve and manufactured sentiments and sympathies nor her recuperation of reality from the jaws of spectacle require or warrant a dismissal of haunting as by definition inadequate to critical thinking or comprehension.

Her denial is axiomatic and appears in a dictate made while commenting on Woolf. "Who believes today that 
war can be abolished? No one, not even pacifists. We hope only (so far in vain) to stop genocide...to bring to justice those who commit gross violations of the laws of war... and to be able to stop specific wars by imposing negotiated alternatives to armed conflict" (2003:5). This is the most significant and revealing statement in the entire book. This "we," this "No one believes war can be abolished today" who hopes in vain, is the sanctioned semi-secret we that directs all the questions and answers and that controls the book's final lamentable conclusion in which the absence of haunting yields a profound incapacity to understand. This "we" is tormented by the human cost of war, including wars it considers just. This "we" is afraid of war and of the armies of the dead war creates. But this "we" assumes that war is inevitable, that war can and will continue, that being "haunted" by photographs of war's destruction is a naïve evasion of this self-evident grown-up fact. Sontag dismisses Woolf's unity of "people of good will" as antiquated, but at the cost of invoking an equally ancient but far more abusive collectivity masquerading as a universal "we." No one today believes that war can be abolished.

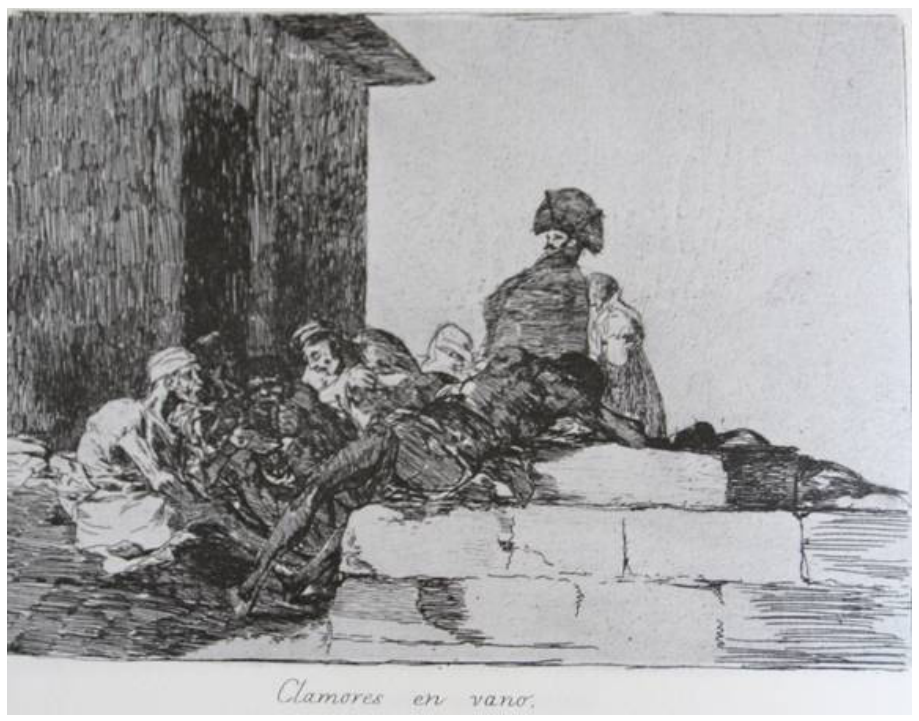

\section{The Way is Hard}

Sontag implies that being haunted is like being in a state of unreflective paralytic shock or disgust, the two rather limited affective states she associates with haunting. But it would be wrong to reduce haunting to shock or disgust, although these may be present. In fact, haunting can foster comprehension and action.

Haunting, at least as I conceive it, is an animated state of existence and perception in which a repressed or unresolved social violence makes itself known to you, sometimes very directly, sometimes more obliquely (Gordon 1997). Haunting is a vivid, sensual or embodied way of being made aware that what's been contained or repressed or blocked is very much alive and present, messing with our various ways of keeping the troublesome and the disturbing at bay. Haunting describes those singular and yet repetitive experiences when home becomes unfamiliar, when the over-and-done-with comes alive, when what's been in your blind-field comes into view. Haunting raises specters, and it jams time - the way we separate the past, the present, and the future. Ghosts arise when repression fails and thus they are not silent, dead, or invisible, but animated with the return or the uprising of what's been repressed. The modus operandi of haunting, why it unsettles and defies detached reasoning, is the recognition that a ghost is present, demanding its due, demanding attention. In demanding your attention and often in frightening you, haunting invariably incites a something-to-be-done. What is to be done and to what end, of course, is never given in advance; every haunting ends or persists along the path, worked on and over by human effort and history, by which its conditions of possibility are broken or renewed. The power of haunting is, in this sense, at least two-sided. It is only ever partially measured by the magnitude of the impact of the harm or the loss or the injustice it registers. The power of haunting must always be equally measured by the brave will and the counter force mobilized against its perpetuation. 


\section{A Collection of Dead Men}

Regarding the Pain of Others concludes with Sontag's "revised version of the end of Gance's J'accuse", her last answer to the question of whether one can "be mobilized actively to oppose war by an image (or a group of images)" (2003:124,122). For her ending image, she chooses Jeff Wall's "Dead Troops Talk (A Vision After an Ambush of a Red Army Patrol near Moqor, Aghanistan, Winter 1986)."

Engulfed by the image, which is so accusatory, one could fantasize that the soldiers might turn and talk to us. But no, no one is looking out of the picture. There's no threat of protest. They are not about to yell at us to bring a halt to the abomination which is war. They haven't come back to life in order to stagger off to denounce the war-makers who sent them to kill and be killed...These dead are supremely uninterested in the living: in those who took their lives; in witnesses-and in us. Why should they seek our gaze? What would they have to say to us? 'We'-this 'we' is everyone who has never experienced anything like what they went through-don't understand. We don't get it. We truly can't imagine what it was like. We can't imagine how dreadful, how terrifying war is; and how normal it becomes. Can't understand, can't imagine (Sontag 2003:125-6).

Sontag replaces Gance's pacifist army of ghosts with a simulated picture of dead men talking aimlessly. Sontag replaces Gance's actual ending-where, war having been abolished, the dead and the living drift into their "renewed world" together-with an unbreachable experiential gulf between the soldier who fights and the civilian who watches. This experiential divide is a sign or a symptom of immobilization, not haunting. One characteristic feature of haunting is precisely the shifting, even the dislocation of experiential divides: for haunting is about being touched, often painfully, by what seemed over, distant, unknown, invisible, irrelevant, impersonal but which is now alive, close, visible, urgent, personal. Obviously, being haunted by war combat if you never were in it is not the same as having been in it. But, in making this gulf permanent and absolute, Sontag replicates the fatalism of war itself. There's no threat of protest because we don't understand, can't understand, can't imagine. Here we see poignantly that when haunting itself has been refused or repressed rather than acknowledged and worked through, there is only the failure of comprehension and imagination, a no-man's-land of a war-torn self-other binary. Don't understand. Don't get it. Can't understand, can't imagine. And a certain loneliness too, it seems to me, for Sontag's "we," bereft of the abolitionist imaginary and its traditions, waits tragically with the silent for what can never arrive: for the dead to speak to you and to exonerate you without your ever speaking to them.

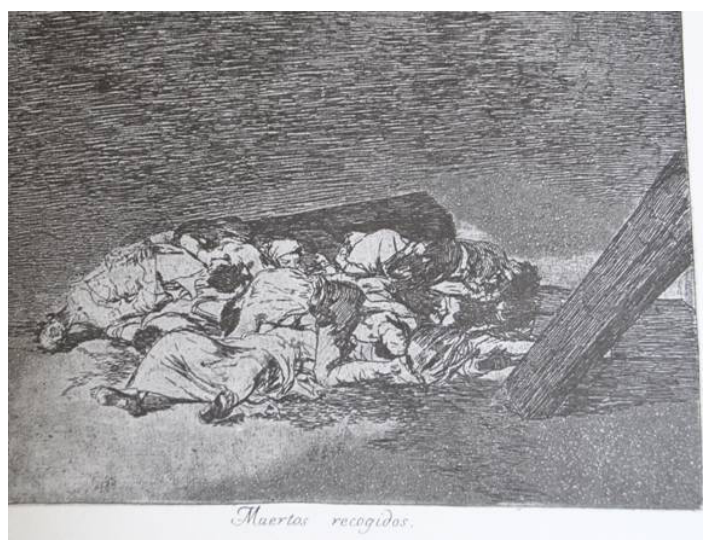

\section{What Courage!}

But history is full of a different "we"-war resisters and deserters of all ages and occupations, peaceful and unpatriotic veterans, clown armies, rebellious women —and this "we" has characteristically, like Gance, been less afraid of ghosts, and unwilling to wait in silence. This "we" makes social movement, even if disorganized and outflanked. [8] We, who believe that abolishing war is necessary and possible, whose standpoint is motivated by that 
belief, are not haunted by a horror that is inevitable, an incomprehensible state of perpetual war. We are haunted by the ways war and militarism organize destruction, disregard and death as the means of economic, political and social life. We are haunted by a horror that is unnecessary, that could have been prevented, that can still be prevented, if we have the will to act. Whatever the limits of our comprehension of war, we understand its fundamental nonnecessity and can imagine the better kind of life we could have without it. Whatever the limits of our comprehension, like all abolitionists, we carry on regardless. A haunting is a summons to an action without precedent, an action that has failed in the past, or, an action that has failed to be attempted, an action that is now, frighteningly, exhilaratingly, entirely up to us.

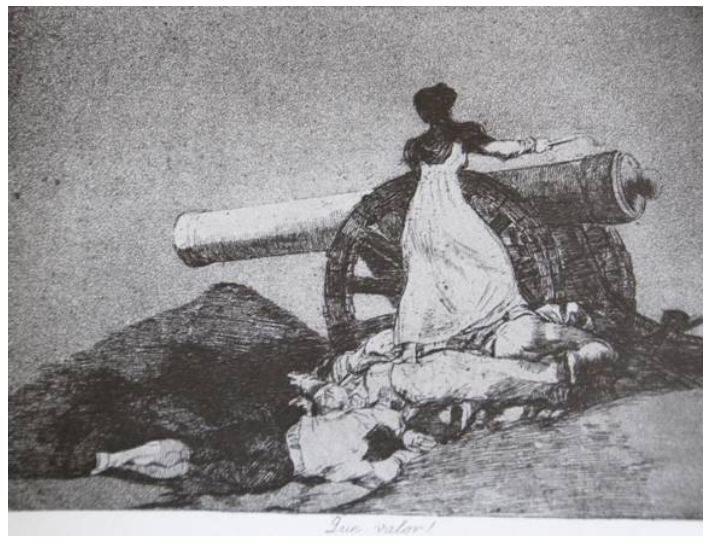

\section{Endnotes}

1. My title and subheadings are from Goya's The Disasters of War (1967). A shorter version of this essay appeared in Cameraworks: A Journal of Photographic Arts Vol. 33, No. 1 Spring/Summer 2006.

2. The March National Security Strategy of the United States begins: "America is at war." The next target of the permanent security war with which the United States is now engaged is Iran, identified in the report as the country who poses the greatest threat to the United States (2006:20).

3. See Milbank (2003) and www.thememoryhole.org, which has posted for viewing and downloading some of the photographs they eventually received (after several appeals) from the Air Force in response to their Freedom of Information Act request.

4. I say amateur because what's not been released are the tapes from the surveillance cameras (CCTV) ubiquitous in all prisons. As Shafiq Rasul and Asif Iqbal note, "We should point out that there were-and no doubt still are-cameras everywhere in the interrogation areas. We are aware that evidence that could contradict what is being said officially is in existence. We know that CCTV cameras, videotapes, and photographs exist since we were regularly filmed and photographed during interrogations and at other times, as well" (Meeropol 2005:28). No doubt, these are one source for Secretary Rumsfield's warning that should all the unreleased photographs be made public, "it's going to make matters worse" and for the Defense Department's continued refusal to release "secret" photographs and videotapes following a federal judge's order. See www. cnn.com and Zernike (2005).

5. It is also, contra Sontag, a powerful story, one taken up equally effectively by J.R.R. Tolkien in The Lord of the Rings where the participation of the dishonored Army of the Dead-all deserters from a former waris necessary to win the famous battle on the Fields of Pellenor outside the city of Gondor, which concludes the War of the Rings and ushers in a long peace. Tolkien was likely to have seen J'accuse; in any event, he himself fought on the front lines at the Battle of the Somme, which took place after Verdun, returning to England with trench fever, severe post-war trauma, and a life-long opposition to war, militarism and military industrialism. See Garth (2003).

6. Sontag's interpretation of Woolf, which reduces a sophisticated and original argument to "the feminist point," is not terribly persuasive on its own terms. For in fact the whole of Three Guineas is devoted to showing that despite the fact that the letter writer claims to share with Woolf the goal of preventing war, their analyses of the causes and nature of war itself are so divergent that his prescriptions for prevention are rejected at the start. The scene where Woolf looks at the photographs occurs in the first few pages and is the context for her shifting 
his terms altogether: "Let us then give up, for the moment, the effort to answer your question, how we can help you to prevent war, by discussing the political, the patriotic or the psychological reasons which lead you to go to war" (1983:11). Three Guineas is important for, among other reasons, demonstrating that peace is more than the absence of war narrowly defined, a framework Sontag studiously dismisses.

7. See, for instance, Rebecca Solnit's (2004) book, a wonderful meditation on how to do activist politics and sophisticated thinking at the same time and thrive!
Coincidentally, she evokes World War I and Virginia Woolf in her first sentences: "On January 18, 1915, six months into the First World War, as all Europe was convulsed by killing and dying, Virginia Woolf wrote in her journals, 'The future is dark, which is on the whole, the best thing the future can be, I think.' Dark, she seems to be saying, as in inscrutable, not as in terrible. We often mistake the one for the other."

8. On war resistance and the abolitionist imaginary, see Gordon (2004), especially the preface, chapters 3 and 25 .

\section{References}

Friedrich, Ernst. [1924] 1987. War Against War. Seattle: Real Comet Press.

Gance, Abel and Steve Passeur. 1938. J’Accuse. Directed by Abel Gance. Paris.

Garth, John. 2003. Tolkien and the Great War: The Threshold of Middle-Earth. Boston: Houghton Mifflin.

Gordon, Avery. 1997. Ghostly Matters: Haunting and the Sociological Imagination. Minneapolis: University of Minnesota Press.

-.---. 2004. Keeping Good Time: Reflections on Knowledge, Power and People. Boulder: Paradigm Press.

Goya, Francisco. 1967. The Disasters of War. New York: Dover Publications.

Milbank, Dana. 2003. "Curtains Ordered for Media Coverage of Returning Coffins.” The Washington Post, October 21, A23.

National Security Strategy of the United States. 2006. The White House, March.

Rasul, Shafiq and Iqbal, Asif. 2005. "Open Letter to President George W. Bush from Two Former Detainees.” In America’s
Disappeared: Secret Imprisonment, Detainees, and the 'War on Terror, edited by Rachel Meeropol. New York: Seven Stories Press.

Solnit, Rebecca. 2004. Hope in the Dark: Untold Histories, Wild Possibilities. New York: Nation Books.

Sontag, Susan. 1977. On Photography. New York: Farrar, Straus and Giroux.

-----. 2003. Regarding the Pain of Others. New York: Picador.

-----. 2004. "Regarding the Torture of Others." New York Times Magazine, 23 May.

Tolkien, J.R.R. 1954. The Lord of the Rings. London: Allen and Unwin.

www.cnn.com. 2004. "Rumsfeld: Unreleased Images 'Cruel and Inhuman," May 8.

Woolf, Virginia. 1938. Three Guineas. New York: Harcourt Brace and Company.

Zernike, Kate. 2005. "Government Defies an Order to Release Iraq Abuse Photos.” New York Times, July 23. 